\title{
UM DIAGNOSTICO DO ABSURDO NA POESIA DE NUNO FÉLIX DA COSTA
}

\section{A DIAGNOSIS OF THE ABSURDITY IN THE POETRY OF NUNO FELIX DA COSTA}

http://dx.doi.org/10.11606/issn.2175-3180.v13i25p112-138

Daniel de Oliveira Gomes I

\section{RESUMO}

Analisamos os livros de poesias intitulados $O$ desfazer das coisas e as coisas já desfeitas (2015) e Agora nós (2012), do autor e psiquiatra Nuno Félix da Costa. Trata-se de um autor contemporâneo de origem portuguesa. Sua poesia se apresenta ao modo de instigantes monólogos filosóficos, como aforismos poéticos beirando o absurdo. Dentre os temas e conceitos que abordamos, constam: os paradoxos da instituição literária; a acefalidade; a arqueologia; a loucura e a liberdade da poesia. Sendo um psiquiatra, o autor, enquanto poeta, vai contra as instâncias de poder, como as da psiquiatria, buscando um diagnóstico do absurdo pela poesia.

\section{PALAVRAS-CHAVE}

Loucura; Nuno Félix da Costa; Poesia contemporânea; Espaço.

\section{ABSTRACT}

We analyze the books of poetry entitled $\mathrm{O}$ desfazer das coisas e as coisas já desfeitas (2015), and Agora nós (2012), book by author and psychiatrist Nuno Félix da Costa. He is a contemporary author of Portuguese origin and his poetry presents himself to the mode of philosophical monologues, such as poetic aphorisms. We studied the following themes and concepts: the paradoxes of the literary institution; the concept of acephality; the notion of archaeology, and poetry as freedom or as madness. Being a psychiatrist and poet, the author goes against the instances of power. Among them, the instance of psychiatry, seeking a diagnosis of the absurd ity by poetry.

\section{KEYWORDS}

Madness; Nuno Félix da Costa; Contemporary poetry; Space.

\footnotetext{
I Universidade Estadual de Ponta Grossa, Ponta Grossa, Paraná, Brasil.
} 
É preciso um diagnóstico do absurdo e é preciso temer as pequenas charadas do destino - Ignoramos o que o cérebro é. Nuno Félix da Costa, Agora nós.

\section{POR UMA ARQUEELOGIA POÉTICA}

Com o seu livro de poesias O Desfazer das coisas e as coisas já desfeitas, o psiquiatra, artista visual e poeta Nuno Félix da Costa produz uma conjectura crítica sobre a relação entre as palavras e as coisas, o cérebro e as imagens, como uma proposição microfísica que quer rechaçar toda linguagem classificadora. Lançado em 200 exemplares pela "Companhia das Ilhas", Lisboa, em 2015, este livro acaba trabalhando ao modo de monólogos, ou solilóquios, poético-filosóficos, um mundo de coisas mais desfeitas do que (per)feitas. Às cabeçadas no acaso, ele não associa o discurso a nenhuma ideologia ou a nenhum dizer em especial, nem mesmo a nenhum fato histórico ou a nenhuma relação com qualquer subjetividade ou comunidade de pensamento. $\mathrm{O}$ poeta rebela-se contra o eterno buscar de respostas a tudo e o querer explicar a tudo, às cabeçadas no acaso, pois fundamos um mecanismo narcísico que quer reconstruir cerebralmente o mundo sem poesia. Construir um mundo sem poesia e sem rebeldia significa, assim, construir um mundo sem o paradoxo da "arché", paradoxo em que o fim e o começo se equivalem.

Jacques Derrida, nas entrevistas disponíveis em Esta estranha instituição chamada literatura (2014), já aludia à instituição literária como uma "instituição sem instituição" (DERRIDA, 2014, p. 60), sob a égide justamente deste paradoxo em que sua origem foi imediatamente a questão do seu fim, o que é sabidamente abordado tanto por Blanchot quanto por Foucault, de igual modo. A literatura, no sentido como a definimos ante outros discursos, alega este paradoxo, na relação com sua própria institucionalidade, "sua história se constrói como uma ruína de um monumento que basicamente nunca existiu" (DERRIDA, 2014, p. 60). Se a literatura é a história de uma ruína, é porque o fim da literatura inaugurou o que chamamos de sua existência, ou a literatura moderna. E, neste fim sendo o seu começo, também há o liame com o paradoxo da linguagem ao infinito a que se referia Foucault.

Como levanta o poema "o porquê das coisas inexplicáveis", de Nuno da Costa, neste mundo, nossa impotência se faz a partir de um sistema linguístico cuja função é fixar (as-fixiar) a tudo, carbonizando as coisas com 
um retardo sígnico em que movemo-nos entre imagens fugidias. A poesia deste autor ensaia, assim, cabeçadas não-cerebrais (um paradoxo, uma acefalidade), ela circula neste território cético que, por sua vez, insiste na turbulência paradoxal da arché da imagem poética contra toda simetria, pois esta turbulência "fere zonas que pensamos inexpugnáveis", são zonas vivas que "saem deste sarcófago de vidro" (COSTA, 2015, p. 87). Quem resta ilusoriamente parado somos nós, com "pés de pedra", ante imagens que fogem, sendo que, como diz o poema, "pesa a idade firme da esfinge", qual seja, a das questões a fazer, a das revelações a bancar para se obter certo poder ante o mundo, um poder narcísico que faz desse poderoso sujeito "uma estatueta carbonizada do eu". O poema principia assim:

As pessoas apaixonam-se por figuras sem as detalhar não na memória mas numa espécie de estômago vazio da alma guardam-na como rações de guerra embrulhadas em pele de [camaleão

Pensam sempre na felicidade - uma digestão de expectativas [elogiosas num território onde o tempo não mata - por lá admitem narcisos. (COSTA, 2015, p. 88)

Deste modo, com algum risco, venho neste ensaio afirmar que o poeta em questão promove algo próximo a um antidiscurso ou, mesmo, uma arqueologia poética, em termos foucaultianos. Acredito que é cabível referir, tomando este poeta, ao conceito de "arqueologia" 2 , uma vez que

\footnotetext{
${ }^{1}$ Assim, a poesia deve ser uma resistência ôntica, um gesto de resistência, talvez, ao facilmente explicável ou à expectativa de revelação da noite, do desconhecido, dos enigmas inalcançáveis que a razão tenta envenenar com explicações mascaradas que prometem poder ir além do desconhecido. O poema intitulado justamente "às cabeçadas no acaso", diz: "O que são as visões depois do envenenamento? Voos / sobre as mutilações anti-metafóricas da própria biografia? / A alma tornou-se plana e num relance abarcamos os vivos / por onde escorrem as palavras senão pelo falso herói que / reconstruímos com as melodias apagadas dos poetas? / Dormimos numa cova escura sobre uma espuma de gladíolos / As frases encurtam-se à covardia dos chacais ao tédio infecioso dos bacilos / Verrugas horripilantes crescem em todo o rosto - é preciso criar / o impossível - Nenhuma visão vai além do desconhecido onde / vivemos e renascemos como simulacro em cada frase - é assim / ter razão - Resistir aos venenos com antídotos também falsos / A única certeza é a do poema fazendo-se da nossa estupefacção / A luz do interior apenas permite a sombra além / da visão que é o que sabemos desconhecer" (COSTA, 2015, p. 89).

${ }_{2}^{2}$ Philippe Sabot, em recente ensaio, nos explica as complexidades de situar tanto o conceito de arqueologia como método, quanto o próprio livro A Arqueologia do Saber, dentro do conjunto de obras de Foucault. Ele situa, junto às ideias do próprio filósofo, como um livro cujo método: "apoyandose en lo que ya há sido hecho, hace una evaluacion de los tanteos y de las imprecisiones $y$, en el fondo, de la diversidad irredutible de los emprendimientos desarrollados bajo el título general de arqueologia" (SABOT, 2019, p. 22). De fato, o termo arqueologia já constava em espécie de evolução conceitual em obras de Foucault antes de Arqueologia do Saber, mas este livro em específico, conforme Sabot, traz páginas programáticas que inovam a noção de
} 
Michel Foucault e Nuno da Costa, ambos, tentam ignorar a transcendência do discurso. Ambos analisam a linguagem, o discurso da normalidade versus os da loucura, procurando constantemente interrupções, suspensões, um lado avesso da palavra; muito embora seja verdade que são estilos e modos de composições muito distintas. (Todo modo, a minha busca é estudar esta obra do autor, visualizando os pontos de contato, sobretudo, com o paradigma da loucura em Foucault, ou melhor, com a analogia despertada entre a linguagem da loucura e uma possível arqueologia do discurso.)

Sendo este lisboense um médico psiquiatra ${ }^{3}$, é interessante como tenta trabalhar a loucura da linguagem, contrapondo-a a uma razão enlouquecida. Instigante como tende a uma microfísica da crítica do discurso a ponto de - sem em qualquer momento escrever qualquer coisa que reenviasse a algum conceito de Michel Foucault ou que demonstrasse alguma influência do pós-estruturalismo francês - provocar o seu "desfazer das coisas" como um gesto de "arqueologia" a percorrer.

Compensaria tomar, no presente ensaio, o filósofo francês em seus estudos sobre o nascimento da clínica e da loucura, mesmo porque Foucault não deixou de notar a medicina como um campo que guardou uma antiga relação com a poesia, em seu primitivo discurso. Na relação da linguagem médica com seu objeto, como diz Foucault, é preciso se dirigir à "região em que as coisas e as palavras ainda não se separaram", para investigar as variações do discurso clínico. Já no prefácio de O Nascimento da Clínica, Foucault se perguntava sobre as mutações da racionalização semântica da linguagem médica. Instigava-o o discurso da experiência médica moderna, ao propor que "o que conta nas coisas ditas pelos homens

\footnotetext{
arqueologia como método no autor. O que seria um trabalho a nível arqueológico com relação ao saber de modo genérico? Basicamente, tem a ver com uma projeção que - mesmo se referindo ao passado, orientada aos pilares e conhecimentos que constituem o saber humano - é "también proyetada hacia adelante de si misma" (SABOT, 2019, p. 23). A arqueologia traz um pressuposto de descontinuidade, é o seu procedimento, e passa também por um profundo estudo discursivo que fundamenta os saberes, analisando não apenas o "sistema" enquanto tal, mas as regras de suas transformações. Como disse Roberto Machado (2000, p. 12), embora Foucault jamais tenha feito exatamente uma arqueologia da literatura, nem por isto o seu interesse pelo campo literário foi esporádico ou marginal, ao contrário, o autor utilizou a literatura, assim como as artes plásticas, para estabelecer relações com o tema da marginalidade, da anormalidade, tendo executado uma ação com o objeto literário em que este já não era propriamente apenas um objeto fenomenológico, mas um complemento frequente tanto do pensamento na relação entre subjetividade e poder, quanto de uma necessidade de operar uma ontologia do presente, sempre em sua transversalidade metodológica.

3 Trata-se de um pintor - sua primeira exposição foi em 1983 - dez anos antes de começar a obrar artisticamente como poeta, em 1993, aos 43 anos de idade. No entanto, suas profissões centrais são a psiquiatria clínica e o trabalho como docente universitário do campo da medicina.
} 
não é tanto o que teriam pensado aquém ou além delas, mas o que desde o princípio as sistematiza" (FOUCAULT, 1998, p. 1). Buscando valores sutis de distinções entre os discursos clínicos e seus métodos de aceitação, que os validam ou não em cada contexto discursivo da evolução histórica da medicina, Foucault questionava, por exemplo, qual a linha decisiva que traçaria a diferença entre uma descrição de membranas como "pergaminhos molhados" ou outra que vê como "películas de clara de ovo"? Mais especificamente, nas palavras de Foucault: "que linha decisiva é traçada entre uma descrição que pinta membranas como 'pergaminhos molhados' e esta outra, não menos qualitativa e metafórica, que vê algo como películas de clara de ovo espalhadas sobre os invólucros do cérebro?" (FOUCAULT, 1998, p. 4). Indo ao século XVIII, ele se perguntava sobre o surgimento de um discurso anátomo-clínico, ponderando a partir de que momento se poderia distinguir que a linguagem médica teria se racionalizado, teria passado de um momento poético, metafórico, a uma cientificidade mais oportuna. E a questão é, em Foucault e em Nuno Félix da Costa, o porquê de, enfim, esta cientificidade ter se tornado a essência simbólica que homologa o admissível, como dizer acerca da loucura; o modo objetivo de dizer as coisas, e por qual razão se tornou a linguagem utilitária da clínica algo mais perfectível para se pensar as coisas feitas, esquecendo que estava a refazer as coisas, o corpo, os órgãos, o cérebro, por meio de um discurso próprio.

Nuno da Costa sonha com um pensamento livre pela poesia, logo, questiona-se sobre a irrelevância de todas as perguntas, quando são elaboradas por um cérebro racionalizado que torna sagrado seu próprio sistema pensante. Como resistir ao cérebro clínico, à razão? Viver sem palavras não seria um mero sonho? Ao menos, deambular pensantes, sem palavras que nos retirassem a vontade de mundo, deambular que pressupusesse uma liberdade real para toda hipótese de linguagem, não apenas a derivada da razão. A pergunta é: haveria alguma perspectiva poético-filosófica de "firmar uma liberdade irreconhecível e deambularmos / resistindo à realidade nominal que nos emudece?" (COSTA, 2017, p. 85). Para tanto, teríamos que notar a linguagem do louco como possibilidade de saber. Na relação do saber, do século XVI, era natural a imprecisão sobre se estamos sonhando ou se estamos loucos, ou seja, uma dúvida sobre as condições de verdade da própria linguagem como fundadoras sobre o sujeito e as coisas, uma perplexidade posta por 
Foucault ao questionar, em certo momento de A História da Loucura: "Entre todas as outras formas de ilusão, a loucura traça um dos caminhos da dúvida dos mais freqüentados pelo século XVI. Nunca se tem certeza de não estar sonhando, nunca existe uma certeza de não ser louco" (FOUCAULT, 1978, p. 54). Foucault despontava com a hipótese de que com o cartesianismo da idade clássica, após a liberdade e valor de verdade do discurso dos loucos renascentistas, repentinamente, o "eu que penso" não posso mais estar louco. Logo, ele se perguntou se "quando creio ter um corpo, posso ter a certeza de possuir uma verdade mais sólida do que aquele que supõe ter um corpo de vidro?" (FOUCAULT, 1978, p. 53). E a resposta: o fato dessa solidez ser o que foi imposto com Descartes ${ }^{4}$, uma solidez aferida no racionalismo, que descartou do discurso do louco uma relevância antes existente, uma vez que passou a notar como extravagante acreditar que se é extravagante, eliminou a dúvida sobre a luz do cérebro, tornando-o o órgão máximo na escala de todos os órgãos do sujeito.

Nuno Félix da Costa, como se se sacrificasse em nome da poesia, mostra ser, para além de poeta, um leitor enlouquecido de muitos clássicos, perdido na missão de atravessar esta noite, este dia apagado que ele mesmo criou. Interessante o modo como Keli Pacheco, partindo dos estudos de Rancière, traz à tona a imagem do "louco da letra", personagem que tem a infelicidade de ler livros, mencionando, por exemplo, protagonistas leitores de clássicos como Madame Bovary ou Werther. A devoção ao livro, ou à escritura, como um reino de infelizes seduzidos. Reino onde "cai-se numa teologia do escritor, numa loucura que obriga um corpo a se sacrificar em nome das Escrituras. Porém, a posição do mestre, do escritor-deus de sua obra, não funciona sem a inclusão da posição do louco da letra" (PACHECO, 2015, p. 999). ${ }^{5}$

\footnotetext{
4 "Quando como Descartes retrocedemos/ pelas tubagens da mente chegamos a uma solução verbal/ e a outra inlocalizável fora da metáfora da plenitude - Não e sim/ ignoram-se - Talvez corram da mesma montanha arrastem diferentes/ climas - os rios cheguem a diferentes mares - Talvez os mares se reúnam/ numa infundada identidade de que nos apoderamos imaginando-a nossa/ De tanto a fazermos existir algum poder a mente terá" (COSTA, 2012, p. 80).

${ }^{5}$ Em verdade, para além de exemplos clássicos como Rei Édipo (de Sófocles), Dom Quixote (de Cervantes) ou Hamlet (de Shakespeare), poderíamos mesmo dizer que a literatura canônica moderna tende a trabalhar muito mais a desrazão do que a razão, pois, alargando a noção desta relação entre loucura e escritura para a noção de loucura e saber, poderíamos citar, ainda, vários outros exemplos de protagonistas delirantes, neuróticos ou ainda loucos da letra, clássicos reféns deste paradoxo do saber infeliz, obsessivo, delirante, moribundo: Gregor Samsa (de Kafka), Simão Bacamarte (de Machado), frei Vicente (de Flaubert), Vladimir e Estragon (de Beckett), o escritor faminto (de Knut Hamsun), Otto Lidenbrock (de Julio Verne), Raimundo Silva (de Saramago), Larsen (de Onetti), Artemio Cruz (de Fuentes), John o Selvagem (de Huxley), dentre muitos outros. Quem sabe a experiência do delírio do saber seja mais incitante do que a experiência da razão
} 
Keli Pacheco acena a casos em que o louco da letra é também o próprio autor, como na obra O Cemitério dos vivos (1953). Assim como ela assinala essa efígie do louco da letra em Lima Barreto, operando uma literatura desesperada pelo diário, ato agonístico que "tecia uma crítica radical à ciência e à medicina psiquiátrica do início do século $X X^{\prime \prime}$ (PACHECO, 2015), permito-me entender Nuno Félix da Costa, enquanto psiquiatra, indo contra as instâncias de poder, mesmo as redes psiquiátricas que normatizam o discurso da razão hoje. Tomasse $o$ pressuposto que o eu-lírico em geral é o próprio eu-do-poeta, poderia imaginar que Nuno Félix da Costa é, igualmente, um refém de uma poesia de urgência, acéfala, de uma literatura desesperada em um mundo racionalizador demais. Não que busque a salvação pela poesia ou, ao contrário, que seu ato como poeta fosse apenas uma secundária ou acessória válvula de escape de sua profissão de psiquiatra. Quem sabe, um ato primeiro. Literatura que, distinto do exemplo de Lima Barreto, não é diário, mas marcada por uma consciência da infelicidade (própria dos reféns enlouquecidos da literatura), por uma consciência arqueológica de que o enlouquecimento (não a própria loucura, exatamente, como dispersão irrestrita do pensamento) pode assegurar o poeta no exílio do mundo. Mas o poeta num exílio do mundo ainda estando dentro dele, com sua palavra enlouquecida, expatriada do sentido.

\section{OLHAR FORA DE SI}

O olhar de Nuno Félix da Costa traz um estro cinemático em que a racionalidade excessiva também pode ser sinal delirante, uma insensatez calculada. Lembre-se que do racionalismo astuto de Medeia fez-se a tragédia de Eurípedes (431 a.C.), e não da loucura, não de uma fuga da razão pelo instinto. É o instinto do horror tomando a razão. Instinto instituindo-se, instinto como instituição. Seria a razão planificada, emoção frígida, sob controle de uma mãe fora de si no seu momento mais racional, muito bem ilustrado no filme de Paolo Pasolini (1969), pelo olhar cabal, à luz do luar, atuado pela atriz grega Maria Callas, com seus olhos enormes

propriamente dita, para os clássicos da literatura, naquilo que Blanchot, Foucault ou Derrida notariam como a transgressividade natural do literário. Basta notar que, mesmo quando trabalha a razão, frequentemente a situa em uma região fronteiriça, desequilibrada. Não é por acaso que quando temos uma personagem como Cândido (de Voltaire), ali está como pastiche, como sátira do otimismo. Isso tudo reforça a noção da infelicidade no reino do literário, aludida por Keli Pacheco. 
e duros, como duas grandes nozes frias. Também, na calma ao chamar os filhos, um a um, para banhá-los nas cenas finais, antes de seu ato premeditado. Talvez, a figura de Medeia seja o maior exemplo literário da racionalidade excessiva como insanidade. Como dirá Isaias Pessotti, numa entrevista à Revista Cult, "a figura de Medéia esconde a constatação até amarga de que a racionalidade não é a perfeição; pode ser até a loucura, quando a serviço da violência do instinto" (PESSOTTI, s/d, p. 58).

Outra obra prima do cinema que trabalha o instinto do horror tomando a razão vem a ser Vestígios do Dia (1993). Este filme contrasta o olhar perfeccionista e acéfalo de um mordomo inglês, interpretado por Anthony Hopkings, com o olhar apaixonado de Emma Thompson, interpretando a governanta que desiste do cargo. O olhar insano e alienado não é, ali, o da desrazão da governanta, mas a mirada da razão excessiva do mordomo. Racionalidade dada nos recintos de uma morada britânica que abrigou reuniões diplomáticas, nos anos 1930, mostrando os bastidores por meio das quais a aristocracia inglesa cooperou à ascensão de ideais nazistas. O típico mordomo inglês tem o cérebro de um esquilo esperto, atento, buscando as nozes da satisfação alheia. Mas, no fundo, seu olhar é vazio, vendo apenas se as ceras e as pratarias estão em ordem. A visão microfísica, obsessiva e especialista gera o silêncio bruto do mordomo inglês, personagem mais preocupado com as simetrias das disposições das taças do que com o conteúdo das conversas políticas que circulam por aquelas mesas, de modo que o insano é o olhar ultra lógico. A loucura é advinda de uma racionalidade excessiva, bem comportada, ela é o próprio controle. $\mathrm{O}$ filme afronta dois olhares, diríamos, de esquilos: o do cargo racional em excesso (o que estoca nozes) versus o do sentimento poético que se entrega à desrazão (o que foge). Olhar incapaz de estar em desordem e que, por isso mesmo, está fora de si.

A noção-imagem, no contemporâneo, do poeta "fora de si" é notável em vários autores cujos versos definidores do eu-poético, por vezes, tangem este limiar do enlouquecimento. Desde o poeta africano Chagas Levene, por exemplo, propondo sua loucura como paradoxal esperança numa dimensão de loucura desesperançosa de Moçambique, ao dizer: "sou uma bomba só desactivada pela loucura / Sou uma nova paranóia alimentada a Coca-cola / publicidade chique e prostitutas crianças / Sou uma vara que se quebra pela própria dureza / Sou um passarinho e não um assassino" (LEVENE, 2007, $\mathrm{s} / \mathrm{p}$ ). Até, por exemplo, o poeta e compositor Arnaldo Antunes, com a letra 
de "Fora de si" (1995), em que, de modo proposital, passa a desafiar loucamente as concordâncias mais básicas da gramática portuguesa: "Eu fico louco / eu fico fora de si / eu fica assim / eu fica fora de mim / Eu fico um pouco / Depois eu saio daqui / Eu vai embora / Eu fico fora de si / Eu fico oco / Eu fica bem assim / Eu fico sem ninguém em mim".

\section{3 Às CABEÇADAS NÃO-CEREBRAIS}

“É preciso um diagnóstico do absurdo e é preciso/ temer as pequenas charadas do destino - Ignoramos o que o cérebro é" (COSTA, 2012, p. 45). Percebo que a poesia de Nuno Félix da Costa ensaia este exílio subjetivo, esta extravagância do enlouquecimento, junto a Foucault, no sentido em que não quer notar o desaparecimento do contratempo da loucura no exercício da palavra, no exercício de toda confabulação de pensamento. Assim, a desatinada poesia do psiquiatra lusitano extravasa extravagante por territórios também utópicos, territórios do sonho, com algumas pinceladas surreais ou irreais, como um cérebro dormente por um efeito anestésico (mas ainda filosófico, buscando um "diagnóstico do absurdo"), em territórios de imagens que não excluem a dimensão da demência e, portanto, não-cerebrais (se pudermos compreender uma concepção de "cerebral", de algum modo, associada ainda ao racionalismo do século XVII). ${ }^{6}$

Nuno da Costa defende uma espécie de espiral histórica acéfala, não encontrando uma diferença substancial entre o mundo primitivo e o atual, ao dizer: "ninguém conhece a infância da humanidade" (COSTA, 2015, p.

\footnotetext{
${ }^{6}$ Como podemos ler em A História da Loucura: "A loucura, cujas vozes a Renascença acaba de libertar, cuja violência porém ela já dominou, vai ser reduzida ao silêncio pela era clássica através de um estranho golpe de força. / No caminho da dúvida, Descartes encontra a loucura ao lado do sonho e de todas as formas de erro. Será que essa possibilidade de ser louco não faz com que ele corra o risco de ver-se despojado da posse de seu próprio corpo, assim como o mundo exterior pode refugiar-se no erro, ou a consciência adormecer no sonho?/ 'Como poderia eu negar que estas mãos e este corpo são meus, a menos que me compare com alguns insanos, cujo cérebro é tão perturbado e ofuscado pelos negros vapores da bílis, que eles asseguram constantemente serem reis quando na verdade são muito pobres, que estão vestidos de ouro e púrpura quando estão completamente nus, que imaginam serem bilhas ou ter um corpo de vidro?' (DESCARTES, Méditations, I, Oeuvres, Pléiade, p. 268.) / Mas Descartes não evita o perigo da loucura do mesmo modo como contorna a eventualidade do sonho ou do erro. Por mais enganadores que os sentidos sejam, eles na verdade não podem alterar nada além das 'coisas muito pouco sensíveis e muito distantes'; a força de suas ilusões deixa sempre um resíduo de verdade, 'que estou aqui, perto da lareira, vestido com uma robe de chambre'. Quanto ao sonho, tal como a imaginação dos pintores, ele pode representar 'sereias ou sátiros através de figuras bizarras e extraordinárias'; mas não pode nem criar nem compor, por si só, essas coisas 'mais simples e mais universais' cuja combinação torna possíveis as imagens fantásticas: 'A natureza corpórea e sua extensibilidade pertence a esse gênero de coisas.' Estas são tão pouco fingidas que asseguram aos sonhos sua verossimilhança - inevitáveis marcas de uma verdade que o sonho não chega a comprometer" (FOUCAULT, 1978, p. 52).
} 
110) ou "Trocamos um cérebro primata muito hierarquizado por uma utopia benfazeja que ninguém habita - Livramo-nos da tribo desconjuntada - Assim irmanados nos aproximamos das casas baixas onde nos pariram coágulos e placentas prenhes de memórias cegas" (COSTA, 2015, p. 111). Ou seja, mesmo que entremos em outros períodos históricos, tecnológicos, informacionais, continuamos com cérebros primatas pautados por memorias cegas (incapazes de apreender o inumerável), o que significa que já eram reféns das hierarquizações comunitárias. Toda memória, mesmo a poética, implica em ambivalente atuação, em que o puro e o impuro convivem. Entretanto, não cabe à poesia adequar imagens, conceber representações, mas sim multiplicar os defeitos da linguagem. ${ }^{7}$ Permanecemos operados pelo primitivismo inato do universo das enunciações, essa espécie de utopia (ou atopia) barroca, para o poeta em sua noção niilista da linguagem. Um "deus robotizável que sabe de nossa muda infância" (COSTA, 2015, p. 110) fez-nos à sua imagem, com seu cérebro bárbaro. Encéfalo que caso o abríssemos, revelar-se-ia em duas partes como uma noz, essas duas partes que se revelam iguais e simétricas.

O cérebro é uma metáfora e se abrimos a noz comemo-la sem distinguir as duas partes que pareciam iguais e simétricas Mas ninguém nos come o cérebro que pode estar infectado pelo vazio atrapalhado das multidões entretidas - Mas ao olhar o firmamento na lua nova vemos a sinfonia não albergar o inumerável nem o ignoto, mas a outra metade do cérebro acompanhar tão alto quanto pode a sinfonia que germina em cada buraco do espaço e o expandem como se houvesse pressa em chegar a algum lugar É o que diz a metade que explica tudo com as letras que repousam nas coisas e fazem as estrelas brilhar à metade que não tem palavras senão as poéticas que constroem mistérios com a qualidade do pensamento - Sem eles para que seriam as metáforas e os deuses e as coisas excessivamente simples como a morte ou as excessivamente complexas como a simetria da noz? (COSTA, 2015, p. 101).

\footnotetext{
7 Em seu Crítica Acéfala (2008), Antelo recorda a definição mallarmeana da poesia como potência multiplicadora que remunera os defeitos da linguagem: "Es decir que el martilleo del recuerdo implica la transgresión de usar una palabra sacer, ambigua y ambivalente, pura e impura al mismo tienpo. Del mismo modo, cuando Mallarmé dice que la poesía remunera los defectos del lenguaje sabe que el munus implicado en esa acción de remuneración, en ese intercambio, es un don pero también una obligación, es decir, un regalo normativo pero asimismo una letra de crédito. Por eso hablaba Mallarmé del double état de la parole, la función transitiva de la lengua convencional, meramente arbitraria, y la función poética o intransitiva del lenguaje que, como último refugio mimético de la historia, especula sobre los efectos concretos de la lengua en las facultades sensibles del hombre" (ANTELO, 2008, p. 147).
} 
Note-se que não se trata do cérebro pensante que define, organiza, mas o cérebro que é pensado, ou melhor, ignorado pelo pensamento, ignorado pela mente. $\mathrm{O}$ cérebro, de tal modo, torna-se objeto menor (artefato, artifício) do pensamento e não o seu sujeito. O sarcasmo de comparar o cérebro humano à noz obviamente está em reduzi-lo simbolicamente de tamanho (algo pequeno e comestível - e se podemos comer o cérebro é porque ele se reduz a uma forma de energia física não superior a qualquer órgão corporal). Contudo, como a imagem da noz desconjuntada em duas partes, a crítica recai à linguagem que é dicotômica, criada por este cérebro dividido. Ironicamente, o poeta descreve uma parte se sobrepondo à outra, a parte poética e imaginativa do cérebro, a que não explica a nada, se deixa classificar como parte (da noz, dividida em dois), porque é considerada pela outra parte. Esta que, em tese, explica a tudo com a linguagem das coisas.

No carioca Alexandre Guarnieri, com o poema "o crânio humano", de igual modo, notamos de maneira (enlouquecidamente) descritiva a relação plástica do cérebro com a noz. Em verdade, ele descreve, na linha de sua estilística de uma mecânica dos fluidos, a caixa craniana, priorizando detalhes ósseos, ranhuras, orifícios etc. Acaba delineando a forma dos miolos e destacando o cérebro humano como uma potencialidade, tanto racionalizadora quanto alucinadora. Nisso, como gerador de energia microfísico, o que o distingue de uma noz? Ou seja, a loucura também faz parte orgânica do cérebro, do mesmo cérebro que é em geral apenas lido pelo seu grandiloquente lado produtivo-utilitário e, portanto, Guarnieri destaca igualmente no crânio outros papéis fisiológicos, por exemplo, o papel da língua: este músculo único que modulou todos os dialetos. $\mathrm{O}$ ofício do pensamento desde o cérebro cumpre um desempenho incógnito, igualizado pela descrição que traça uma objetificação poética dos detalhes intracranianos, buscando uma espécie de voyerismo biológico. Vejamos:

compósito ósseo por sobre cujos orifícios inteiramente desobstruídos, encaixam-se os módulos dos olhos, narinas, da boca, e ouvidos; a tampa de louça calcinada pelo couro, (marfim fissurado sob cabelo) um trono ocupa o topo desta cúpula / uma armadura de juntas, parcialmente encoberta por ranhuras em cruz, pelas quais, de sua furna interna (o antro intracraniano), escapam-lhe 
tantos juízos - como se fugissem pássaros deste receptáculo craquelado; lacrado sob a caixa manchada do crânio humano, jaz, moldado nos miolos, à forma de uma noz que alucina e racionaliza, o gerador unigênito - razão pela qual congelam o cérebro de um gênio -, de cada inédita eureca, e de todas as idéias velhas, de séculos, de décadas, guardadas em antiquíssimas bibliotecas; sob o palato, escondida, esteve a língua, quase retilínea (um único músculo, infatigável, modulou todos os dialetos), a dentição se encaixava, cobrindo-a , esta fila de lanças fincadas, abaixo das maxilas, e na base da mandíbula (GUARNIERI, 2016, p. 73).

Assim como Cesar Aira o faz em El Cerebro musical ${ }^{8}$, a poesia de Alexandre Guarnieri e, mais intimamente, de Félix da Costa, tentam, aos seus modos, dissecar este cérebro, averiguar as partes. Tal cérebro que não muda, sempre delegando a um segundo plano a poesia (como aquilo que germina do inexplicável), é capaz de uma linguagem excêntrica, simplificando em símbolos o mundo, para dizimá-lo na utopia babélica da distinção do homem ante outros seres, ante outros "deuses", "deuses preparados para um futuro mesmo sem nós" (COSTA, 2015, p. 110). O simples é a morte, o complexo é a simetria, o cálculo. $\mathrm{O}$ cérebro é uma simples metáfora de avaliação criada por um lado só, um lado

\footnotetext{
${ }^{8}$ Em determinado ensaio, já de algum tempo, analisei a novela poética El cerebro musical de Cesar Aira, editada alternativamente em 2007, pela Eloisa Cartonera. No sentido de uma mal escritura que desafia o cérebro cartesiano, a partir de um cérebro musical, poético, prosódico, filosófico, etc. é que me permito aproximar a escrita de Nuno Félix da Costa à de Cesar Aira. Quando escrevo que Aira dá a entender que sua obra acarreta "a malescrevência como uma potência dessubjetivadora, uma potência de maquilagem, de sabotagem artificializante, dessublimadora, dos pilares estéticos que nos guiam uma noção do belo." (GOMES, 2014, p. 28), de algum modo, quando hoje leio a poesia de Nuno da Costa, me deparo com algo semelhante. O que eu explicava naquele ensaio era o modo como Cesar Aira se lançava com seu cérebro musical desde um desfazer das coisas indo para a direção das coisas já desfeitas... O leitor de Aira, assim como o de Costa, me parece ser um leitor por vir, situado numa região onírica, sem tempo ou espaço seguros, numa temporalidade não linear. Se Aira faz um teatro da não-linearidade, pela prosa poética, evoluindo de um desfazer para uma narração já desfeita, eu diria que Costa faz um teatro da não-linearidade pela poesia prosaica. Ambos desfazem das coisas, partindo de uma crença escritural componente das coisas já desfeitas. A crença numa imagística desafiadora do logos, que o balança pela musicalidade e anacronismo, que vai numa linha circense em Cesar Aira, diria que em Nuno Félix da Costa vai numa linha mais séria, mais moderada pelo exercício descritivo-filosófico o qual faz parte de seu estilo. Sei das diferenças entre estes autores contemporâneos, mas aproximo Nuno Félix da Costa do tema da "malescritura", tratado em Aira, assim como postulei que "o que Aira nos informa é a arbitrariedade e a errância dos elementos das histórias que conta, como acordes dissonantes ao acaso, navegando na partitura da ficção; ou digo melhor: o abandono musical da ancestral linearidade do logo sé o que Aira alerta como captura necessária no pensamento do escritor" (GOMES, 2014, p. 30).
} 
abandonado. E é assim, um pequeno nada diante da dissimetria maior da existência (este reino dos deuses ${ }^{9}$ ). Um pedaço gerador de energia como uma noz que pode ser comida.

A linguagem do cérebro obsessivo pela simetria, que é o humano, sendo o grande elemento antagônico tematizado pela poesia de Nuno Félix da Costa, é um mecanismo imutável que finge agarrar, no entanto, apenas "toca e larga". É que a linguagem nunca responde, ela joga com o que aparece, de modo que gaguejamos na superfície da superfície, criando ilusões de profundidade. "Quando gostamos de uma coisa e começamos a fazer perguntas a linguagem joga com o que aparece - finge agarrar mas toca e larga" (COSTA, 2015, p. 106). A poesia, neste drama da linguagem que toca e larga, que ilude o agarramento impossível do sentido das coisas, é mais dada à limpidez, mesmo sendo dissonância e perplexidade. Logo, o cérebro obsessivo pela simetria e a ordem é mais propício à enfermidade, vindo de um império de sujidade mental. Ele percebe mesmo uma falta de higiene no cérebro racional, da simetria, pois as perguntas capazes de serem feitas deste cérebro apenas são "as cuecas das coisas" (COSTA, 2015, p. 106).

[Nossos cérebros produzem] máscaras venezianas que jogam com o equilíbrio arrevesado nos caminhos da fuga - Escutemos o vento configurar indícios que só existem na lentidão absorta da consciência - assim o desejo morre no acaso e gaguejamos - a pergunta escorrega para o lixo sem outro efeito que a queda do pó nas superfícies inúteis da vida (COSTA, 2015, p. 106).

\footnotetext{
${ }^{9}$ Lembro, aqui, do texto "A Linguagem ao Infinito" (1963), no qual Foucault o inicia referindo-se à Odisseia (como Ulisses manteve, soberanamente, o seu canto diante da morte que o ameaçava repetidamente). Foucault trata a linguagem como um espelho ao infinito, na relação com a morte, associando a noção do relato, da narração, à ideia de lidar com o infortúnio enviado pelos deuses. Escrever para não morrer, poetizar para não morrer, relatar o infortúnio para espantar a morte... A linguagem é um sistema espelhado que se reflete no infortúnio, na linha da morte, havendo uma possível relação entre a morte e a representação da linguagem para si mesma. Segundo Foucault, os mortais recebem dos deuses os infortúnios para que relatem poeticamente, no canto que cria o ciclo que a afugenta e a aproxima do herói, do sujeito. Por isso, dirá: "O infortúnio inumerável, dom ruidoso dos deuses, marca o ponto onde começa a linguagem" (FOUCAULT, 2009, p. 48). Vem a ser nesse prisma foucaultiano da relação entre morte e linguagem que me arrisco a ler Nuno da Costa, por exemplo, na obra Agora nós (2012). Ali, de modo mais intenso, o autor define constantemente em versos um triangulamento cíclico entre poetas/deuses/morte: “Quando o poeta se nos dirige nunca/ ficamos indiferentes - não é só a voz que lhe ouvimos/ mas o silêncio do inferno que nos abre a porta - Rumamos ao exílio que nos descreveu - navios de sangue da plenitude" (COSTA, 2012, p. 68); “Estamos no esterco da história - é quando os deuses se manifestam cada vez maiores e desconchavados efeito da complexidade cultural dos humanos (...) / Isso poderá recomeçar por uma necessidade de perfeição que a linguagem corrompeu" (COSTA, 2012, p. 96). "para compreendermos bem a vida temos de a olhar de todos os ângulos como moribundos" (COSTA, 2012, p. 90).
} 
De tal modo, a própria poesia é incessantemente impotente porque, embora mais salutar, é ainda linguagem desde um cérebro ancestral, ou seja, pertence a uma estrutura remota, a uma vontade de esplendor que se repete antes de nós, administrando as faces semânticas entre camuflagens venezianas. Embora Deleuze afirmasse que a arte contempla a morte e, deste modo a resiste, a arte não é exatamente um instrumento de comunicação racionalizador. A morte é sempre um movimento, a arte seria o ato de resistência subversiva ao fim (que é movimento). No paradigma deleuzeano, o desejo se põe como uma usina de produção, posto ser sempre um reaver de outros desejos em série, outras máscaras venezianas de desejos (mas o desejo não ligado à encenação, como pensaria dramaticamente a psicanálise, por exemplo). Nesse prisma, o que o cérebro deseja são outros desejos, volições produtivas, deseja-se algo sempre no contexto de agenciamento do sentido, a progressão racional de seu ser a partir do desejo. Se vivemos hoje numa sociedade da celebração da informação, sociedade como ápice biopoderoso de controle dos desejos, para pensar também foucaultianamente, a poesia deve ser um ato subversivo que faz o desejo morrer no acaso, em queda nas superfícies inúteis da vida, como diria o verso citado acima de Nuno da Costa. O desejo é, portanto, uma produção social, cerebral, trabalhosa, progressiva, empilhadora, acumulativa, criativa. É sabido o quanto Deleuze e Foucault dedicaram-se a criticar a fundamentação do conceito de desejo psicanalítico, oferecida muito na lógica da perda, da subtração. Todavia, nessa ótica antipsicanalítica, eles arriscaram notar o desejo fundamentado na iminência produtiva, no atilamento do ganho, das relações de poder da confissão etc.; ou seja, leram o desejo de modo oposto para violarem, colapsarem, por assim dizer, a concepção dominante passiva no inconsciente que era própria do desejo freudiano. Nesses termos, o desejo vem a ser algo construído e não apenas reprimido, ele é, então, uma vontade de esplendor, um movimento, uma reincidência produzida cerebralmente. Do mesmo modo, o poeta é um alguém que desliza como efeito de desejo, nas cadeias significantes, cognoscentes, cerebrais, da vontade da poesia. O poeta acéfalo, como uma causa do desejo poético.

Há instantes no poema que não nos pertencem mas uma vontade de esplendor que se repete e tanto podemos pensar em alguém que a mova como dizermos na linguagem tudo enraizar e se ajardinarmos bem uma palavra como 'deus' ela fá-lo-á existir ainda que só na 
contingência falante do cérebro humano - a solução necessária à solidão e à ausência (COSTA, 2015, p. 107).

Foucault descreve a patologia do encéfalo, dizendo que se teria inaugurado um discurso próprio, positivado, quando Bichat, Recamier e Lallemand descrevem terem usado de um "martelo terminado por uma superfície larga e delgada". Foucault retira breves fragmentos de um texto do início do século XIX, de Lallemand, que continua numa linha extremamente objetivista de estilo, descrevendo como se abre uma cabeça, lembrando quase como uma operação técnica de receita culinária:

Procedendo por pequenos golpes, estando o crânio repleto, não pode haver um abalo susceptível de produzir desordens. É melhor começar por sua parte posterior, pois quando só há o occipital a ser quebrado, ele e frequentemente tão móvel que os golpes resvalam... Nas crianças muito novas, os ossos são flexíveis demais para serem partidos, muito finos para serem serrados; e precise corta-los com fortes tesouras (FOUCAULT, 1998, s/p).

Foucault notou a ingenuidade do discurso médico no início do século XIX, demandando uma relação mais moderna entre as palavras e as coisas, entre o dizível e o manifesto aos olhos, o visível. Para ele "as formas da racionalidade médica penetram na maravilhosa espessura da percepção, oferecendo, como face primeira da verdade, a tessitura das coisas" (FOUCAULT, 1998, p. 4).

Por vezes a fala de Foucault, em O Nascimento da Clínica, tende também a aproximar-se do estilo poético, por exemplo, quando diz: "é preciso se colocar e, de uma vez por todas, se manter ao nível da espacialização e da verbalização fundamentais do patológico, onde nasce e se recolhe o olhar loquaz que o médico põe sobre o coração venenoso das coisas" (FOUCAULT, 1998, p. 5). Em geral, Foucault nos mostrava que, no triângulo estabelecido entre doença, sintoma e signo, o papel do médico é um papel de tradutor poético. O discurso do especialista satura a multiplicidade dos sintomas visíveis e enunciáveis em novos enunciados, como se aplicasse uma metáfora pré-disposta que transforma o sofrimento subjetivo e individual na doença em uma realidade de discurso médico a curá-la, generalizada e especializada (num golpe de vista). Em sua gênese, o procedimento clínico propõe: o médico restitui pela linguagem, no discurso, o que é visto e, em certa medida, desaloja e traduz a fala, a queixa, 
do paciente para o discurso clínico. A visão clínica, fundamentalmente, pressupõe a audição do discurso do paciente, logo é também uma audição daquilo que o sujeito confessa. É nesse sentido que Foucault notaria, primordialmente, o sintoma se confundindo com o universo sígnico. $\mathrm{O}$ sujeito que confessa é tomado como causa do signo. O signo é o próprio sintoma, dirá, na verdade, em O Nascimento da Clínica. Se os sintomas acompanham uma ordem natural, esta ordem natural, bem como todo o roteiro das manifestações patológicas, fala uma linguagem aparelhada por uma ordem sempre límpida e objetiva. Nesse sentido, o ser de toda patologia é enunciável, plenamente. A verdade clínica advém de um "quadro" dado por uma relação entre o que é visto e o que é ouvido, de modo que aquilo que é visível e o que é enunciável dão-se numa aliança, no campo médico. Tal como o filósofo, o olhar clínico pressupõe uma estrutura cerebralizada de objetividade na qual, como diz Foucault, "a totalidade do ser se esgota em manifestações que são seu significantesignificado" (FOUCAULT, 1998, p. 109). Foucault (1998, p. 109) também articula: "a clínica abre um campo que se tornou visível pela introdução do domínio patológico de estruturas gramaticais e probabilísticas".

Quem sabe o momento da anamnese clínica tenha um parentesco maior com a filosofia e a poesia, do que com o empirismo: "O olhar clínico tem esta paradoxal propriedade de ouvir uma linguagem no momento em que percebe um espetáculo. Na clínica, o que se manifesta é originariamente o que fala" (FOUCAULT, 1998, p. 122). Foucault mostrava como a questão da percepção no campo da medicina, que saiu de um "jardim de espécies" para um domínio real dos acontecimentos, retirou-se de um lugar de observação pura para um topos de percepção muito mais poderoso. Ao notar que a medicina começou a usar de vocabulários por vezes estatísticos e matemáticos, como "grau de certeza", "percentagem de dor" etc., nota-se certa perplexidade foucaultiana quando, como diz o autor francês, "o que lhe dava valor de signo não era uma aritmética dos casos, mas sua ligação com um conjunto de fenômenos" (FOUCAULT, 1998, p. 217).

Entretanto, Foucault mostrará que o século XIX comporta uma mudança no campo fenomenológico da medicina, pois ela passará a ser governada diretamente pela soberania do olhar. Esta soberania do olhar já constante na mirada da anatomia patológica será componente da medicina classificatória. As lesões e doenças do corpo passam a constituir uma leitura direta no discurso médico, como num "golpe de vista" dirigido a 
onde se assinala a doença. O olhar clínico acabou por confundir-se com o olhar puramente anátomo-clínico na medicina ocidental. Nos ensina Foucault que o olhar de modo geral tende a totalizar, já o golpe de vista, tende a especificar, ele fragmenta, decupa. A época do fisiologista Bichat registra esta transição em que a medicina dos sintomas regride ao passo que a medicina dos órgãos entra em expansão ordenada pela lógica própria da anatomia patológica. Bichat, em seu Traité de Mambranes (1799), tão relido por Foucault, marca, para o filósofo, o momento de um deslocamento para o positivismo do olhar clínico. O golpe de vista atua em nível plano, é um olhar epistemológico de superfície, mesmo quando se abre um corpo, o dissecando para análise descritiva. Foucault afirma que Bichat e seus discípulos de anatomia "desvelavam na profundidade das coisas as ordens das superfícies" (FOUCAULT, 1998, p. 149) ${ }^{10}$.

\title{
4 A NATUREZA DA CONSCIÊNCIA É O NADA INVENTADO
}

Inventamos o nada na infância. Olhar-infância, olhar infante. O discurso do mundo pautado no olhar inaugural, como olhar a tudo pela primeira vez, este é o olhar infantil e poético. Olhar que permeou a filosofia e que Foucault notou em O Nascimento da Clínica.

\begin{abstract}
A criança se torna a senhor imediato do adulto na medida em que que a verdadeira formação se identifica com a própria gênese do verdadeiro. Incansavelmente, em cada criança, as coisas repetem sua juventude, o mundo retoma contato com sua forma natal: ele nunca é adulto para quem o olha pela primeira vez. Quando abandonar os seus velhos parentescos o olho poderá se abrir ao nível das coisas e das idades; e, de todos os sentidos e saberes, ele terá a habilidade de poder ser a mais inábil, repetindo agilmente sua longínqua ignorância. A orelha tem suas preferencias, a mão seus traços e suas dobras; o olho que tem parentesco com a luz, suporta apenas seu presente. O que permite o homem reconciliar-se com a infância e alcançar a permanente nascimento da verdade e esta ingenuidade clara, distante e aberta do olhar (FOUCAULT, 1998, p. 72).
\end{abstract}

Mas o discurso de Nuno Félix da Costa não se dirige apenas à medicina, ou a um âmbito determinado do discurso, um campo do saber.

\footnotetext{
${ }^{10}$ A anatomia de Bichat (falecido muito jovem, aos 30 anos) acabou por criar descrições ordenadoras dos tecidos mucosos, serosos e fibrosos, que encaixavam generalidades concretas no sistema corporal e em grupos de doenças.
} 
Pergunto-me: como associá-lo à Foucault, se sua poesia, e com ela sua crítica à linguagem, é muito mais dispersa, não se situando num quadro histórico, mas em todo campo de acontecimentos discursivos que caracterizam o homem versus a poesia? Para ambos, a linguagem se homologa à distância das coisas e, no entanto, de modo ambivalente, também como aquilo que mimetiza, ou mesmo autoriza, a presença das coisas. As palavras dos dois autores, apesar de suas diferenças obvias no campo da filosofia ${ }^{11}$ ou da poesia, são em si mesmas ficções terroristas, uma vez que elas simulam uma representação a qual não parecem acreditar, para poder implodir as suas demarcações pela linguagem. Contudo, esta representação, por isto mesmo, é acarretada apenas na coragem política de sabotar a própria linguagem, de desconfiar intensamente das verdades que a linguagem possa suscitar. ${ }^{12}$ Trata-se de acreditar que a poesia ou a escrita possui forças políticas ${ }^{13}$ que apenas $o$

\footnotetext{
${ }^{11}$ Diz Nuno da Costa, no poema "não vamos enlouquecer": “(...)não queremos pensar como poetas com o real mal digerido dos filósofos" (COSTA, 2012, p. 117).

12 "Foucault dizia: 'Não há ficção porque a linguagem se coloca à distância das coisas; a linguagem é essa distância, a luz onde as coisas estão e a sua inacessibilidade, o simulacro onde se dá a sua presença; e qualquer linguagem que, em lugar de esquecer essa distância, se mantém nela e a mantém nele, qualquer linguagem que fala dessa distância avançando nela, é uma linguagem de ficção. Pode, então, atravessar qualquer prosa e qualquer poesia, qualquer romance e qualquer reflexão, indiferentemente' (Foucault, 1994, p. 281)./ Por tudo isso, o conceito da ficção se torna incontornável para a definição do trabalho inclassificável que desenvolve Foucault, quem assumia voluntariamente que na sua vida não escrevera outra coisa que fiç̧ões. Com isso não pretendia dizer que sempre se mantivera fora da verdade, mas que fizera trabalhar em certo modo a ficção na ordem do verdadeiro, tentando induzir efeitos de verdade com um discurso que não se adequava aos critérios do verdadeiro que imperavam no seu tempo. /Por um lado, a ficção opera em algumas das obras de Foucault como nos romances de Verne: 'vozes sem corpo combatem para contar a fábula' (Foucault, 1994b, p. 507), isto é, os sujeitos da enunciação multiplicam-se, deslocando constantemente as relações entre o narrador, o discurso e a fábula. Assim, por exemplo, na História da loucura, cada fábula tem a sua voz, cada voz dá lugar a uma nova fábula, segundo um movimento que faz com que as personagens saiam da fábula à que pertencem para converter-se nos relatores da fábula seguinte, como numa espécie excêntrica desses jogos de bonecas russas (falam os médicos, os loucos, os regulamentos, os mandados de detenção, os filósofos, os poetas, etc.)" (PELLEJERO, 2018, p. 247).

13 "Em Políticas da Escrita, Jacques Rancière relembra que a escrita é um ato político, no senso de que há um desdobramento, 'uma relação da mão que traça linhas ou signos com o corpo que ela prolonga; desse corpo com a alma que o anima e com os outros corpos com os quais ele forma comunidade; dessa comunidade com sua própria alma'. Assim, a escrita se torna política porque 'seu gesto pertence à constituição estética da comunidade e se presta, acima de tudo, a alegorizar essa constituição'. Antes de ser um sistema de formas constitucionais ou de relações de poder, uma ordem política é uma certa divisão de ocupações, a qual se inscreve, por sua vez, em uma configuração do sensível: em uma relação entre os modos do fazer, os modos do ser e os do dizer; entre a distribuição dos corpos de acordo com suas atribuições e finalidades e a circulação do sentido; entre a ordem do visível e do dizível. O que dá forma à comunidade é a partilha do sensível. Como a escrita separa o enunciado da voz que o enuncia, ela prejudica a ordem do fazer, do ver e do dizer, quer dizer, ela é órfã, e por essa razão, Rancière a relaciona com a democracia: 'à condição do escrito sem pai corresponde o estado de uma política sem pastor nem arquè. Pois a democracia não é um modo particular de governo. Ela é, bem mais radicalmente, a forma da comunidade repousando sobre a circulação de algumas palavras sem corpo nem pai - povo, liberdade, igualdade...'" (PACHECO, 2015, p. 993).
} 
poeta ou o filósofo pode conhecer. Trata-se de escavar, mesmo com suposições aparentemente de menor alcance, efeitos desestabilizadores, ou melhor, de investigar engrenagens que concatenam suas sequências de palavras, ou o que Foucault nominou como "dispositivos", visando a um curto-circuito que "não recupera a imagem".

São vida estas suposições de menor alcance - Só nelas conseguimos ver as engrenagens se conciliarem num propósito que dizemos [transparente

como uma estrofe ou inviável - Então dizemos a vida falhar mas procuramos um efeito poético - um curto-circuito na sequência de [palavras

que não recuperam a imagem - No poema existem maiores que a vida forças que só um poeta conhece - Por isso acreditamos nele porque não se refere à vida quando diz a vida falhar mas a um mundo no fundo das palavras que tanto alegra como faz chorar (COSTA, 2012, p. 98).

Vale lembrar que isto também estará na noção mais ampla de arqueologia em Foucault. No princípio de Arqueologia do Saber, Foucault articulava sobre seus livros anteriores e, especificamente, que, "em Naissance de la clinique, o recurso à análise estrutural, tentado várias vezes, ameaçava subtrair a especificidade do problema colocado e o nível característico da arqueologia." (FOUCAULT, 1999, p. 18). Foucault teria tentado estudar as configurações internas do discurso da medicina, assim como outros discursos em outras obras anteriores, buscando suas contradições invisíveis, mas, ainda muito agarrado à história e às fragmentações dos discursos. Por outro lado, no estudo mais arqueológico do saber em geral, Foucault busca já o pano de fundo dos acontecimentos discursivos, começando um traçado sabotador da história, um caminho que procederá, adiante, na sua fase da genealogia. É esta escavação de um pano de fundo o que me parece surtir uma relação com a poesia que estudamos. Ambos, Foucault e Nuno Félix da Costa, acabam recusando arqueologicamente a história de modo mais proeminente, porque escavam engrenagens, dispositivos, suspendendo mais de imediato sua assiduidade, sua constância como verdade documental, buscando antes "uma população de acontecimentos no espaço do discurso em geral" (FOUCAULT, 1999, p. 30). 
Mas, se não é possível mais confiar na palavra ou confiar na confiança que acreditávamos estar depositada nas palavras, como suportar a solidão, este falar com as paredes? Como conviver com esta palavra enlouquecida no fato de que tudo é incomunicável, mesmo no cotidiano mais corriqueiro? Nuno da Costa, no poema "o dia a dia", propõe que

a maior parte das pessoas enlouquece de uma forma estabelecida - atirase ao chão esbraceja possuída por algo que é outro - que dissolve a malha do eu numa lava porosa/ Sobre os sentidos a metamorfose instantânea das nuvens que cruzam o palco da vida (COSTA, 2105, p. 15).

Para este poeta, é como se uma pessoa mais consciente fosse menos "cerebral", contudo, uma pessoa mais poética é sempre mais consciente porque é uma pessoa mais perdida no ser, por isso, é preciso "voar que é a imaginação do amor" (COSTA, 2015, p. 15). A poesia é o real (sem razão) atrás da realidade, um entrelugar intelectual ${ }^{14}$. O poeta, acedendo a este real aquém do real, pode declarar quando a vida falha: "só um poeta pode declarar quando a vida falha" (COSTA, 2015, p. 97). E não que "só um

\footnotetext{
${ }^{14}$ Sendo a poesia este entrelugar intelectual, poderíamos considerá-la como mera dessubjetivação do sujeito? Ou seja, uma poesia que não atinge a representatividade intelectual do sujeito, do caput, da cabeça, de um grupo comunitário, etc.? Ou poderia ser considerada como a niilista inoperância de sua própria racionalidade? Ou melhor, este entre-lugar intelectual da poesia seria mais como firmar uma desidentidade ou uma acefalidade? Trabalhando a experiência da modernidade como uma crucial experiência de entrelugar teórico e crítico que não apenas suspendeu a racionalidade mas atuou no interstício entre ficção e teoria, entre poética e política, Raul Antelo escreve sobre a acefalidade periférica na modernidade. No caso, ele dirigiu-se a tal acefalidade bataillana, como conceito viável também desde Nietzsche, Blanchot e Nancy, nos discursos tangenciais à latino américa. Refiro-me à obra Crítica Acéfala (2008), lançada na Argentina. A partir dessas visões, será que poderíamos tentar entender uma acefalidade, nesses termos, vigente na poesia contemporânea de Portugal, com autores pósmodernos (para, aqui, usar uma expressão rápida)? Penso em autores como Nuno Félix da Costa, José Emilio Nelson, Isabel Mendes Ferreira, Luis Serguilha e Jaime Rocha... Diria que sim, mas em sentido um pouco distinto do que o definido por Antelo: não exatamente, de se convergir a uma busca de identidade cultural local pelo fantasmático e a hibridez, fragmentando o sujeito como identidade, lendo-o como intensidade. Mas, sim, também, na atuação, na pulsão, na coreografia paradoxal de muitos valores globais, sejam linguísticos, históricos, e outros. Tento notar como estes poetas, e nitidamente Nuno Félix da Costa, parece-me que acusam não apenas a deliberação falsa do mundo gerado pela racionalidade humana - racionalidade tradicionalmente pautada num dogma conceitual de "cabeças pensantes", "indivíduos unidos em grupo" - mas também a questão blanchotiana anárquica de comunidade inconfessável, noção em liame com a acefalidade, desde Georges Bataille. Blanchot, no belo livro A Comunidade Inconfessável, partindo de Bataille, mostrava que o sujeito nunca pensa sozinho (quase chega ao ponto de afirmar que a cabeça pensante deve ser ilusão do próprio pensamento); ele aludia à hipótese batailliana de basilar insuficiência do sujeito, ou princípio de incompletude, ante a comunidade, principio dado como uma abertura que ordena a possibilidade de se ser. Caímos em um assunto ontológico, a existência de cada um demanda a pluralidade de outros, mas esta comunidade e toda comunidade é sempre finita, para Bataille e Blanchot, pois ela sempre confere uma "sobreindividualidade" que apenas reitera e não resolve o problema bataillano da basilar insuficiência do sujeito. Acredito que a poesia seria um discurso intelectualmente consciente desta insuficiência basilar e das ambivalências de valor da comunidade, desde Nuno Félix da Costa. A poesia deve ser, assim, um discurso acéfalo.
} 
poeta" declare a vida falha, mas, também, "um poeta só". Blanchot (2002) prontamente notaria que escrever sobre esta vida falha é falar a sós, quando tudo nos escuta, é uma experiência de enlouquecimento. No poema "enlouquecemos com a consciência ou além dela?", dirá o poeta:
A natureza da consciência - isso sabemo-lo - é o nada inventado perder-se nas próprias estratificações - Tudo o que recebe de uma evidência desligada dos nervos engrena no ritmo do Mundo - a coreografia sustenta o exterior da língua e uma alucinação que a [ocupasse levava-nos pelos riachos da dor até a paisagem impronunciável Experimentamo-la quando falando a sós tudo nos escuta - o corpo [abre-se ao entendimento onde não podemos existir - $\mathrm{O}$ medo fragmenta-nos o seu ácido lambe-nos - gotas do espanto carcomem a pele - [personagens
alheias vêm sobre nós - dizem-se o teatro da redenção - Não nos [pertence
tamanha nitidez - pensamos como um armamento mudo no espelho que nos refaz - Por baixo a vergonha dos sonhos - nossos por serem ancestrais como o declive do rio desde a rocha inóspita pelo acaso [olímpico
e pelo inferno até a foz onde os esperamos com a máscara da [consciência (COSTA, 2015, p. 100).

Se a natureza da consciência é o nada inventado e um gesto perdido de estratificações, vale remeter a Foucault, afinal, ele mostrou que, a partir de uma multiplicidade de objetos, não era viável admitir um discurso referente à loucura, um conjunto de enunciados alusivos à loucura. Notou que os enunciados alusivos à Psicopatologia, espalhados em épocas históricas distintas, valiam-se de modos distintos quando se referiam ao seu objeto específico, como experiencia individual e social, que era a loucura. No entanto, ele notou que "a unidade do objeto 'loucura' não nos permite individualizar um conjunto de enunciados e estabelecer entre eles uma relação ao mesmo tempo descritível e constante." (FOUCAULT, 1999, p. 37). Jamais poderíamos, como aponta o filosofo francês, perguntar pelo nada da loucura, assim como não poderíamos perguntar pelo nada da consciência. Como inquirir ao próprio ser da loucura, aferindo-a numa espécie de verdade secreta e muda, o que se pode dizer ou não ao seu respeito?

Ou seja, o que se considera por loucura é constituído muito mais por um conjunto de enunciados com regras próprias que articularam sobre o 
louco, de caráter purgativo da sociedade dita normal, do que uma eventual descrição pura da alienação e suas distintas correlações. E dirá, ainda, que esse conjunto de enunciados sobre a loucura não se relaciona com um apenas objeto, definitivamente, conservando uma "idealidade inesgotável" (FOUCAULT, 1999, p. 37), de modo que, nos discursos clínicos dos séculos XVII ou XVIII, o objeto que é colocado como seu correlato,

não é idêntico ao objeto que se delineia através das sentenças jurídicas ou das medidas policiais; da mesma forma, todos os objetos do discurso psicopatológico foram modificados desde Pinel ou Esquirol até Bleuler: não se trata das mesmas doenças, não se trata dos mesmos loucos (FOUCAULT, 1999, p. 37).

Por fim, a inversão está feita: como voltar a perguntar genuinamente com a antiga inocência de nossos ancestrais o que há atrás das coisas, atrás da mente, atrás das estrelas, atrás das verdades astrais? A metaforicidade da razão: não é a poesia que inventa, simula, cria máscaras, metaforiza as coisas, mas, sim, o excesso de razão da linguagem. Em Nuno da Costa, o conceito de escritura como deriva não passa exatamente por indagar nem por responder, seja sobre a consciência ou sobre a loucura, mas advém como uma experiência de enlouquecimento, coreografia sígnica para os limiares de realmente ninguém. Através deste enlouquecimento poético, talvez, venhamos a recobrar antigas verdades, venhamos a efervescer dissonâncias necessárias com relação a um universo que à poesia delegou um plano secundário.

A consciência só pode ser uma máscara abandonada pelo verdadeiro rosto que é a multiplicidade indescritível da vida, que é a poesia ao aguardo, a poesia-aquém; logo, vestir como que uma máscara inóspita da consciência, ceder a um teatro de redenção, abdicar aos sonhos de nossos ancestrais. São sonhos envergonhados, punidos, que tentaram e tentam ainda rivalizar com a magia do firmamento. Babel. Punição ancestral. Uma vez que, com nossos cérebros, "imitamos presépios afundados" (COSTA, 2012, p. 94), ou, posto que perdemos as antigas verdades cujos lugares poderíamos confiar mais plenamente (próximas eram do indefinido e das nuvens da poesia. Hoje, num mundo regido por cérebros mais abstratos, mais cartesianos, sólidos, duvidamos menos e respondemos mais). Somos, aliás, massas sem tempo, sem vontade, suspensas entre a passividade e a espontaneidade, resultantes do fim do social, como diria Jean Baudrillard 
(2004). Não dispomos mais de tempo para dúvidas, num mundo onde a tecnologia informacional e o fim de culturas simbólicas fazem proliferar o sentido acolá do próprio sentido. E cada vez mais ignoramos as velhas culturas simbólicas que antes projetavam os sujeitos para a dimensão de multidões silenciosas, como se nas massas houvesse uma energia política reprimida, um sentido positivo a expressar.

Baudrillard (2004) acusou esta fantasia de uma razão popular, ilusão simbólica de um cérebro das massas como refletor do social, massas postas às sombras por certas forças ideológicas. O sociólogo francês aperfeiçoou uma crítica profunda da razão do social, tal como se criticou a razão histórica, a razão política e a razão revolucionária. Quem sabe, fosse interessante pensar, por exemplo, como a massa brasileira não tem refratado mais o social e como, talvez, nesse sentido, a vitória do presidente Jair Bolsonaro nas eleições brasileiras tenha sido mais um sintoma involucionário da desrazão das massas. Um sintoma de indiferenciação, de despojamento do sentido racional e nacional. Oposta à noção de massa crítica, revolucionária, que explode sua razão ao momento de exprimi-la, teríamos a noção de uma massa involucionária, que sempre implode uma força de inércia, de desilusão do mundo político. Como assinala Baudrillard, a informação excessiva - esse racionalismo violento do mundo ultra informacional - não produz e nem retira a energia interna das massas, ao contrário, ela gera mais e mais massa acéfala. E a massa, por sua vez, na era da globalização, é um processo mais forte que quaisquer meios de comunicação, ela forma um único processo com eles, ou, como diria Baudrillard "mass(age) é mensagem" (BAUDRILLARD, 2004, p. 23). O sistema se perpetua em signos sem essência.

Nisso, voltando a Nuno Félix da Costa, uma poesia filosófica da negatividade se impõe como resistência política questionadora a esse "universo inventado" das massas idealizadoras. É deste modo que, para o poeta, a poesia é um dispositivo revolucionário (ou involucionário) paradoxal, porque nos aproxima da loucura e da morte, das antigas verdades, com aquilo mesmo (a linguagem) que banca uma suprema necessidade de normalização e fragmentação, estratificação absolutizada das coisas feitas em palavras. Como desinventá-las? Como desfazer as coisas?

Talvez as antigas verdades se tenham perdido e hoje nos encontramos num universo inventado - Nas ilhas astrais as leis das coisas decalcam-se de um cérebro muito abstracto 
onde cada um depositou a sua humanidade - Depois já não se percebe o que movimenta as nuvens - as árvores que nelas enraízam os peixes que as atravessam - os pássaros amam-na e comem-nas Lá adiante - onde desaparecem - o que tremeluz? Engolidos num buraco negro os nossos desejos e as suas verdades confundem-se Nós e os poemas de amor as amantes e o luar atravessando as nuvens e os peixes de todos os tamanhos e de todas as épocas confundimo-nos Às escuras sem espaço para desejar nem qualquer razão para mentir o que será do cérebro que argumentava a civilização? As energias fundem-se num bigue-bangue inadiável Outra poesia surgirá? (COSTA, 2012, p. 95)

Para desfazer as coisas é preciso desobedecer a suas leis. As leis das coisas decalcam-se de um humanismo abstrato, impalpável, uma linearidade racionalista que, em geral, aplaca a vida, as nuvens, os pássaros, ou seja, engolindo sempre todo o movimento, o fluxo, do mundo natural num buraco negro do sentido, da fixação. A demanda da poesia e da criação surge, então, como uma espécie de corda de resgate da dança linguística, em que o cérebro do poeta deve largar inadiavelmente a armadura que depreende de tais leis fixadoras para, então, pensar sobre um outro futuro, pós-civilizacional, digamos, que suspeitasse da infalibilidade de toda ordem cerebral. A desordem intuitiva ocasiona uma emoção criativa que também é sentido e pensamento, uma melodia imaginaria que, por exemplo, Valèry já notara nos paradoxos, em pleno nascimento do humanismo, do cérebro renascentista de um artista como Leonardo Da Vinci. Artista cuja assombrosa lição de liberdade do pensamento assediou o cogito ergo sum, pautando-se numa liberdade artística abissal. De tal modo, Valèry por exemplo, considerava a poesia como um gênero não tão distante da filosofia.

Isso dito, diante de um cérebro muito abstrato onde depositamos nossa humanidade, na lei linear da comunidade em que cada um lança sua narcísica esperança de ser, a poesia deve se tornar um discurso acéfalo, porque apenas ela poderá compreender o fim do social. A poesia poderá compreender nossa errônea busca de felicidade pelos caminhos vazios da alma, pelos caminhos do fascínio por figuras. Como proferiram seus versos, ainda uma vez:

As pessoas apaixonam-se por figuras sem as detalhar não na memória mas numa espécie de estômago vazio da alma guardam-na como rações de guerra embrulhadas em pele de camaleão 
Pensam sempre na felicidade - uma digestão de expectativas elogiosas num território onde o tempo não mata - por lá admitem narcisos (COSTA, 2015, p. 88).

Para este poeta, a poesia deve ser acéfala, porque também atingirá, para aquém de uma postura histórica, sociológica ou psicológica, o saber em que a existência humana é sempre um questionamento do próprio existir. A poesia como consciência acéfala é vital para o pensamento porque poderá compreender vivamente, questionando a si própria, que a comunidade é ela mesma um questionamento radical da vida, pois encaminha à morte seus membros, como pensaria Nancy. Porque poderá compreender que a linguagem poética pode vir a ser um questionamento radical das relações que excluem relações, ou seja, das relações comunitárias finitas (em um sistema de semelhanças e dissemelhanças criado desde a linearidade do logos). A ausência de comunidade não é o seu fracasso, como Blanchot leu a Bataille, e uma poesia acéfala tentaria alcançar esses limites inventivos, ou melhor, limiares, estes liames. É como compreendo Nuno Félix da Costa, autor de uma poesia merecedora de atravessamentos filosóficos (ex)cêntricos.

\section{REFERÊNCIAS}

ANTELO, Raul. Crítica Acéfala. Buenos Aires, Editorial Grummo, 2008.

ANTUNES, Arnaldo. "Fora de si". Ninguém. Direção artística: Sérgio de Carvalho. São Paulo: RCA, 1995.

BAUDRILLARD, Jean. A sombra das maiorias silenciosas: O fim do social e o surgimento das massas. Tradução de Suely Bastos. São Paulo: Brasiliense, 2004.

BLANCHOT, Maurice. La comunidad Inconfessable. Editora nacional: Madrid, 2002.

COSTA, Nuno Félix da. O desfazer das coisas e as coisas jà desfeitas. Lisboa: Companhia das Ilhas, 2015.

COSTA, Nuno Félix da. Agora nós. Lisboa: Cortex Frontal, 2012.

DERRIDA, Jacques. Essa estranha instituição chamada literatura. Uma entrevista com Jacques Derrida. Belo Horizonte: UFMG, 2014.

FOUCAULT, Michel. As palavras e as coisas. São Paulo: Martins Fontes, 1987. 
FOUCAULT, Michel. Arqueologia das Ciências e História dos sistemas de Pensamento. Org. Manuel Barros da Motta. Rio de Janeiro: Forense Universitária, 1999.

FOUCAULT, Michel. "A Linguagem ao Infinito". In: Estética: Literatura e Pintura, Música e Cinema. Org. Manuel Barros da Mota. Rio de Janeiro: Forense Universitária, 2009.

FOUCAULT, Michel. História da Loucura na Época Clássica. São Paulo: Perspectiva, 1978.

FOUCAULT, Michel. O nascimento da Clínica. Petrópolis: Vozes, 1998.

GUARNIERI, Alexandre. Corpo de festim. Guaratinguetà: Penalux, 2016.

GOMES, Daniel de Oliveira. "Sobre a consideração foucaultiana de nome próprio". Uniletras, v. 34, p. 11-24, 2012.

GOMES, Daniel de Oliveira. "O último Foucault e o retorno transversal aos gregos". Revista Archai: Revista de Estudos sobre as Origens do Pensamento Ocidental, v. 1, p. 37, 2012.

GOMES, Daniel de Oliveira. "O sorriso kafkiano de Foucault". Fórum Linguístico (Online), v. 8, p. 159-164, 2012.

GOMES, Daniel de Oliveira. "Baudrillard versus Foucault: revolvendo concepções quanto à noção de poder na literatura foucaultiana". Anamorphosis. Revista Internacional de Direito e Literatura, v. 2, p. 69-95, 2016.

LEVENE, Chagas. Tatuagens de Estrelas. Maputo: Ndgira, 2007.

MACHADO, Roberto. Foucault, a filosofia e a literatura. Rio de Janeiro: Zahar editor, 2012.

PACHECO, Keli Cristina. "O louco e o refém da letra em políticas da escrita de Jacques Rancière" In: Anais do VIII Ciclo de Estudos da Linguagem. I Congresso Internacional de Estudos da Linguagem. UEPG e Universidad de Córdoba, junho de 2015. Disponível em: http://sites.uepg.br/ciel/2015.

PELLEJERO, Eduardo. "Foucault com Verne: os jogos ardentes da ficção". In: SOUZA, Pedro de, GOMES, Daniel de Oliveira. Foucault com outros nomes: Lugares de Subjetivação. 2ª ed. Ponta Grossa: Ed.UEPG, 2018.

PESSOTTI, Isaías, "Miragem da Literatura, ditadura da imaginação". Entrevista a José Guilherme Ferreira. Revista Cult, n.7, Dossiê digital Literatura \& Loucura, s/d, pp. 58-62. 
SABOT, Philippe. "El estatuto del acontecimiento em el pensamento de Michel Foucault de Las palavras y las cosas a La Arqueologia del saber". In: LOPEZ, Cristina, RAFFIN, Marcelo e COLOMBO, Augustin (orgs.). Pensar com Foucault hoy. Relecturas de Las Palabras y las cosas y La voluntad de saber. San Martin: UNSAN EDITA, 2019.

Recebido em 1 de fevereiro de 2021

Aprovado em 16 de setembro de 2021

Daniel de Oliveira Gomes

Professor associado na Universidade Estadual de Ponta Grossa. Doutor e Mestre em Literatura pela Universidade Federal de Santa Catarina. Graduado em Letras pela Universidade Estadual de Ponta Grossa. Pós-doutorado em poesia junto ao Centre de Recherches Interdisciplinaires sur le Monde Lusophone, na Université Paris Nanterre.

Contato: setepratas@hotmail.com

iD https://orcid.org/ 0000-0003-0325-9846

A Revista Desassossego utiliza a Licença Creative Commons Attribution que permite o compartilhamento do trabalho com reconhecimento da autoria e publicação inicial neste veículo - Attribution-NonCommercial-NoDerivates 4.0 International (CC BY-NC-ND 4.0), e reconhece que os Autores têm autorização prévia para assumirem contratos adicionais separadamente para distribuição não-exclusiva de versão dos seus trabalhos publicados, desde que fique explicitado o reconhecimento de sua autoria e a publicação inicial nesta revista. 